\title{
Nuanced Narratives: Reporting with Critical Race and Feminist Standpoint Theories
}

\author{
Emily Margaret Pelland \\ West Virginia University, emp0014@mix.wvu.edu
}

Follow this and additional works at: https://researchrepository.wvu.edu/etd

Part of the Adult and Continuing Education Commons, African American Studies Commons, Curriculum and Instruction Commons, Educational Technology Commons, Elementary Education

Commons, Other American Studies Commons, Other Education Commons, Photography Commons, Secondary Education Commons, Social and Philosophical Foundations of Education Commons, and the Women's Studies Commons

\section{Recommended Citation}

Pelland, Emily Margaret, "Nuanced Narratives: Reporting with Critical Race and Feminist Standpoint Theories" (2019). Graduate Theses, Dissertations, and Problem Reports. 3804.

https://researchrepository.wvu.edu/etd/3804

This Problem/Project Report is protected by copyright and/or related rights. It has been brought to you by the The Research Repository @ WVU with permission from the rights-holder(s). You are free to use this Problem/Project Report in any way that is permitted by the copyright and related rights legislation that applies to your use. For other uses you must obtain permission from the rights-holder(s) directly, unless additional rights are indicated by a Creative Commons license in the record and/ or on the work itself. This Problem/Project Report has been accepted for inclusion in WVU Graduate Theses, Dissertations, and Problem Reports collection by an authorized administrator of The Research Repository @ WVU. For more information, please contact researchrepository@mail.wvu.edu. 
Nuanced Narratives: Reporting with Critical Race and Feminist Standpoint Theories Emily Margaret Pelland

A professional project report submitted to The Reed College of Media at West Virginia University as a fulfillment of the requirements for the degree of

Master of Science in Journalism

\author{
Joel Beeson, PhD., Chair \\ Dana Coester, M.A. \\ David Smith, M.A. \\ Milton Kent, B.S.
}

Morgantown, West Virginia

2019

Keywords: critical race theory, feminist standpoint theory, journalism, history, documentary, virtual reality, African American, underreported, experimental, minority

(C) Copyright 2019 Emily Margaret Pelland 


\section{ABSTRACT \\ Nuanced Narratives: Reporting with Critical Race and Feminist Standpoint Theories}

\section{Emily Margaret Pelland}

The Google Expedition titled WWI Era Through the Eyes of the Chicago Defender explores African American experiences during the early years of the Great Migration (19101970). Conventional journalism relies on the false idea that journalists are meant to be, and can be, objective, outside observers. This report provides tools for journalists to create more nuanced, thorough storytelling endeavors. This report describes the theoretical framework and intent of the Virtual Reality (VR) project for students in grades 8 and above. It utilizes Feminist Standpoint Theory (FST) and Critical Race Theory (CRT) to cultivate a VR experience that acknowledges particular, overlooked aspects of American history. The Expedition utilizes photographs and articles from the Chicago Defender, archival stills and motion pictures, and 360-degree images of present-day locations throughout the United States, including Chicago and Waco, TX. Using Google Expedition, students wear a VR headset while a teacher guides the student through the Expedition, which was created through the lens of CRT and FST to help students question current narratives and stereotypes that still pervade society and mass media. 


\section{Acknowledgements}

Committee:

Dr. Joel Beeson

Professor Dana Coester

Professor David Smith

Professor Milton Kent

Project Team:

Beverly Scott

Colonel Eugene Scott

Tricia Faulks Kelly

Brianna Robinson

Dana Coester

To all the reporters and editors of the Chicago Defender and the Pullman Porters for delivering the news.

To those who risked their lives migrating from the South to the North in search of the American Dream. My greatest hope is for students to have a greater understanding of their stories through this project. 


\section{Table of Contents}

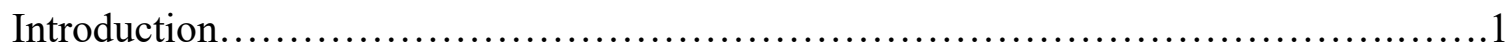

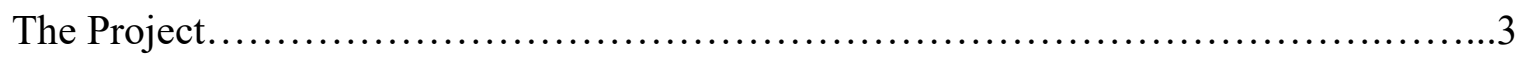

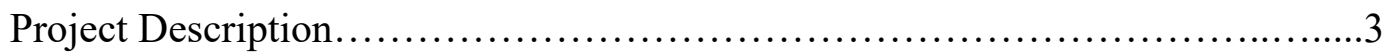

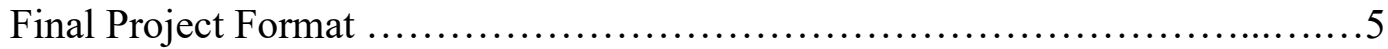

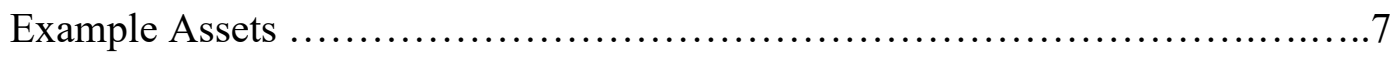

Behind the Scenes Images ............................................ 10

Professional \& Educational Qualifications .......................................13

Skill Development........................................................... 13

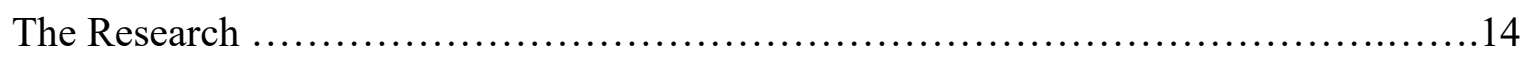

Research Statement ....................................................... 14

Intended Audience ........................................................... 14

Project Methodology ................................................... 14

Project Challenges .................................................... 16

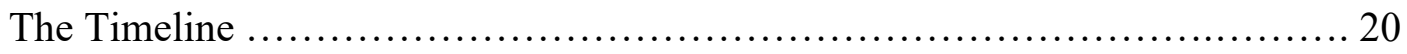

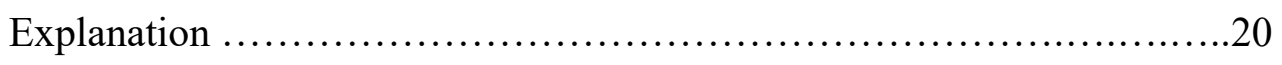

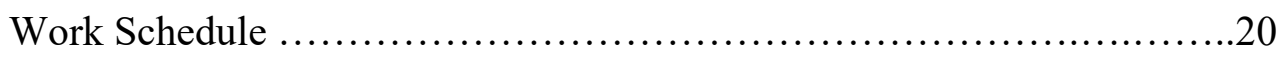

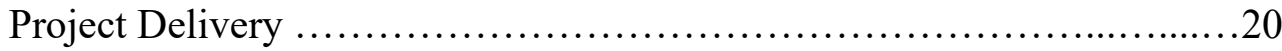

Literature Review: Critical Race Theory and Feminist Standpoint Theory to Cultivate NonFiction Stories............................................................... 20

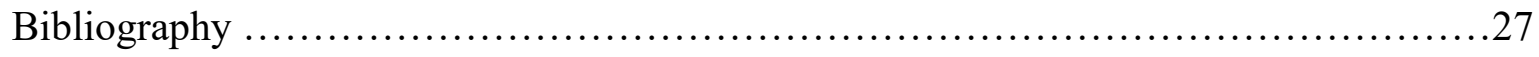




\section{Introduction}

What is the value of American history if it does not include all Americans? How can new technology converge with old or traditional technology to share historical non-fiction stories? How can journalists challenge conventional storytelling methods through the creation of more nuanced, thoughtful stories? This report discusses the Google Expedition WWI Era Through the Eyes of the Chicago Defender, a VR experience for students in grades 8-12 and above. This unique project combines archival footage with VR technology to cover some topics that are typically overlooked, particularly in educational curricula. Using the frameworks of CRT and FST, the project explores history through the lens of race and gender to produce a VR experience that best represents African American history in the WWI period.

The WWI Era: Through the Eyes of The Defender is a culmination of collaborative efforts between members of the Bronzeville, Chicago community and outside journalists. The journalists brought their multimedia and technical expertise, but lacked the connections to and understanding of the Chicago community of the Bronzeville, Chicago community members. Using archival footage and narratives co-written and edited by local voices, the project allows the audience to experience aspects of the African-American experience during the WWI era (ca. 1914-1920) through articles from the Chicago Defender, one of the most prominent AfricanAmerican newspapers that still reports to this day.

In this VR experience, users are virtually transported to sites of critical historical moments, including the Great Migration, the Jim Crow South, women's suffrage, Chicago's allBlack $370^{\text {th }}$ Infantry, post-war racial violence, and the birth of the modern civil rights movement. The juxtaposition of century-old archival footage with present-day images reveals striking similarities, providing the audience with the opportunity to contemplate the institutions of racism 
and sexism that continue to trouble Black ${ }^{1}$ communities and ultimately stifle Americans as a whole.

The endeavor was framed using Critical Race Theory (CRT) and Feminist Standpoint Theory (FST) in order to produce a nuanced project about African-American experiences during the First World War. CRT challenges deficit narratives that define the lives of People of Color. Deficit narratives are narratives that portray a group as lesser-than or in a negative way to place them in a devalued role in society. Deficit narratives for African Americans include stories that portray them as inferior in particular ways, such as not being able to escape poverty because of lack of will, or being targeted by police because of a pre-disposition to crime; thus perpetuating the stereotype that African Americans are always poor and criminals.

FST asserts that people have a perspective that incorporates race, class, gender, birthplace and so on. Journalists have lived under the misperception that they can be objective and unbiased. This viewpoint has perpetuated systemic racism, misogyny and classism. This report and the project focuses mainly race and gender, but class-based issues are also an aspect of the African-American experience. Ultimately, this report on the Google Expedition will provide tools for other journalists and creators to improve the quality of work that represents people beyond the Euro-centric scope that has historically dominated worldwide. This is not to say that European history is irrelevant to understanding America, but there is more to the story of American history.

\footnotetext{
${ }^{1}$ In this report, white in reference to people is lowercased because it is about race, while Black in reference to people is capitalized because it applies to a group of people who lost the opportunity to express their African cultures because of slavery. People of European countries have been given the liberty to do so.
} 


\section{The Project}

\section{Project Description}

This project utilizes VR technology, juxtaposing 2D videos (including archival footage) with present day images to drive the story through articles from the Chicago Defender. The project is published through the Google Expeditions app, and it includes eight chapters on the topics of: the Chicago Defender, the Great Migration, Jim Crow laws, African American suffragettes, the $8^{\text {th }}$ Illinois National Guard, the $370^{\text {th }}$ Infantry, the Red Summer and the Ku Klux Klan (KKK), and the birth of the modern civil rights movement.

The project also utilized panoramas. A panorama (pano) is a 360-degree still image or video that is best viewed through a virtual reality headset so the user may look unhindered as to simulate actual reality; it can also be viewed on a desktop with a player that allows users to scroll to view the whole pano. Each pano has Points of Interest (POIs) that provide additional information for the students about each topic.

The creators of the project included two individuals from the Bronzeville community: Beverly Reed Scott, a former reporter for the Chicago Defender, and Colonel Eugene Scott, the former publisher for the Chicago Defender. (They are also married.) They were vital in factchecking and infusing nuance to the topics in each panorama and providing essential local knowledge and historical insights that would not have been available by researching in archives alone.

As African Americans, Beverly and Colonel Scott infused a deep human element into the facts that the white producers alone could not authentically emit. For the project, the Scotts acted as experts and co-producers. Without their valuable contributions, the project would be lifeless, meaning it would only have the facts without the human experience. With CRT and FST in 
mind, it was vital that the project team included experts who journalists may not normally include. Had this project utilized conventional journalism methods, it would have been more insular and might have relied only on people traditionally considered experts like academics, elected officials, or doctors. This project needed to expand the idea of what an "expert" is using the lens of the aforementioned theories.

The Scotts were those experts needed for this project of knowledge-creation. Those who have the power to create historical content affect how history is shared with others, and it was vital to the project to collaborate with African Americans with strong connections to the story, the history, and the Chicago Defender. They edited scripts, as well as contributed their actual voices for the voice-overs of the videos. This helped to ensure the facts were not only accurate but also contained more nuanced emphases than would have been possible by involving only white/non-Black writers. The aura of the narration instilled the human element needed to take the Expedition beyond a basic teaching aid. Beverly's writing infused a heartbeat that none of the outside journalist team could accomplish, and her voice-overs were particularly poignant. The Colonel also gave deeper insight into military history that is not widely available online. With varied backgrounds and experiences, the interaction between producers during production provided important lessons for us as white journalists during production, which will be discussed later in this report.

While this Expedition was only one long-term project, the theories that were used and the experiences gained from it can act as a tool-kit for other journalists and creators to consider in their creative processes. The Expedition had the advantage of time and money that most newsrooms do not have. Journalism at large is experiencing serious reductions in funding, personnel, time and other resources. This report hopes to provide overburdened newsrooms and 
reporters with the resources to create stories that better represent the history of people situated in their time and place.

\section{Final Project Format}

The final project format is a Google Expedition, a supplementary teaching aid in the form of a VR experience for students. The Expedition, plainly put, is about the African-American experience during World War I as portrayed through reports by the Chicago Defender. The project, targeting grades 8-12, combines archival footage with present day footage within this experimental, new medium of virtual reality. The VR experience allows students to explore three-dimensional space within a 360-degree still image augmented with two-dimensional 30second videos of a related topic. In this experience, the person views the panoramic images and videos in the VR headset through the app on their mobile device while a teacher uses an iPad to direct the journey for one or multiple students. The "leader" (teacher) leads a "user" (student) through the Expedition. The leader can pause and advance the journey.

The Expedition consists of eight panoramic images with audio that are viewed in a VR headset. Each panoramic scene has at least one with Point of Interest (POI), which is a video for this project. There is one beginner question, one intermediate question, and one advanced question, as well as descriptions of each pano and POI. For this Expedition, Google required titles, descriptions, panoramic images, and $2 \mathrm{~d}$ videos that overlay the pano — which is technically an Augmented Reality (AR) feature — each with specific limitations.

During production, my duties included project management, archival research and retrieval, audio and video recording and editing, and ensuring the entire project met the standards sent by our contact with Google Expeditions. 
Pano one is about the history of the Chicago Defender and its creator Robert Abbott. The video discusses how the Chicago Defender objected to the showing of the film The Birth of a Nation, which employed stereotypes of African Americans that still exist to this day. The film also provided visuals for the Ku Klux Klan to emulate, such as the pointed white hoods for uniforms.

Pano two focuses on Jim Crow laws in the South. This chapter includes two videos: the first is about the economic slavery of sharecropping, and the second is about separate yet unequal education under Jim Crow laws.

Pano three describes the Great Migration, which was the largest movement of Americans in American history. Roughly six million African Americans traveled from the South to northern cities between 1910-1970 to find jobs, homes, and property. They wanted to achieve the American Dream. The video displays how the Chicago Defender promoted migration of Black Americans to the North.

Pano four represents African American women during that era. The video describes how Ida B. Wells and other Black suffragettes persevered against the racism of white suffragettes. Leaders of feminist movements have often been openly racist, and the suffragette movement suffered for years because of its racism.

Pano five discusses the $8^{\text {th }}$ Illinois National Guard. The video provides a short history of the $8^{\text {th }}$ Illinois and the Houston Race Riot in August 1917.

Pano six describes the $370^{\text {th }}$ Infantry, which was the only all-Black infantry with Black commanding officers during WWI. The video describes the exemplary work and honor of the soldiers despite ill treatment. 
Pano seven revolves around post-war violence and the Red Summer riots. The video discusses the rebirth of the KKK after WWI.

Pano eight, the final chapter, is about the birth of the modern Civil Rights Movement. The video is about Lt. Earl B. Dickerson, a Civil Rights lawyer.

\section{Example Assets}

The following documents are some of the assets for Pano five about Black women in WWI. Each pano consists of similar elements. This chapter of the project is of particular interest as it revolves around both Critical Race Theory (CRT) and Feminist Standpoint Theory (FST), which are theoretical references on which I will base my analysis of this production experience.

\section{Pano Five: Women in WWI}

Pano Title: Black women in the WWI era

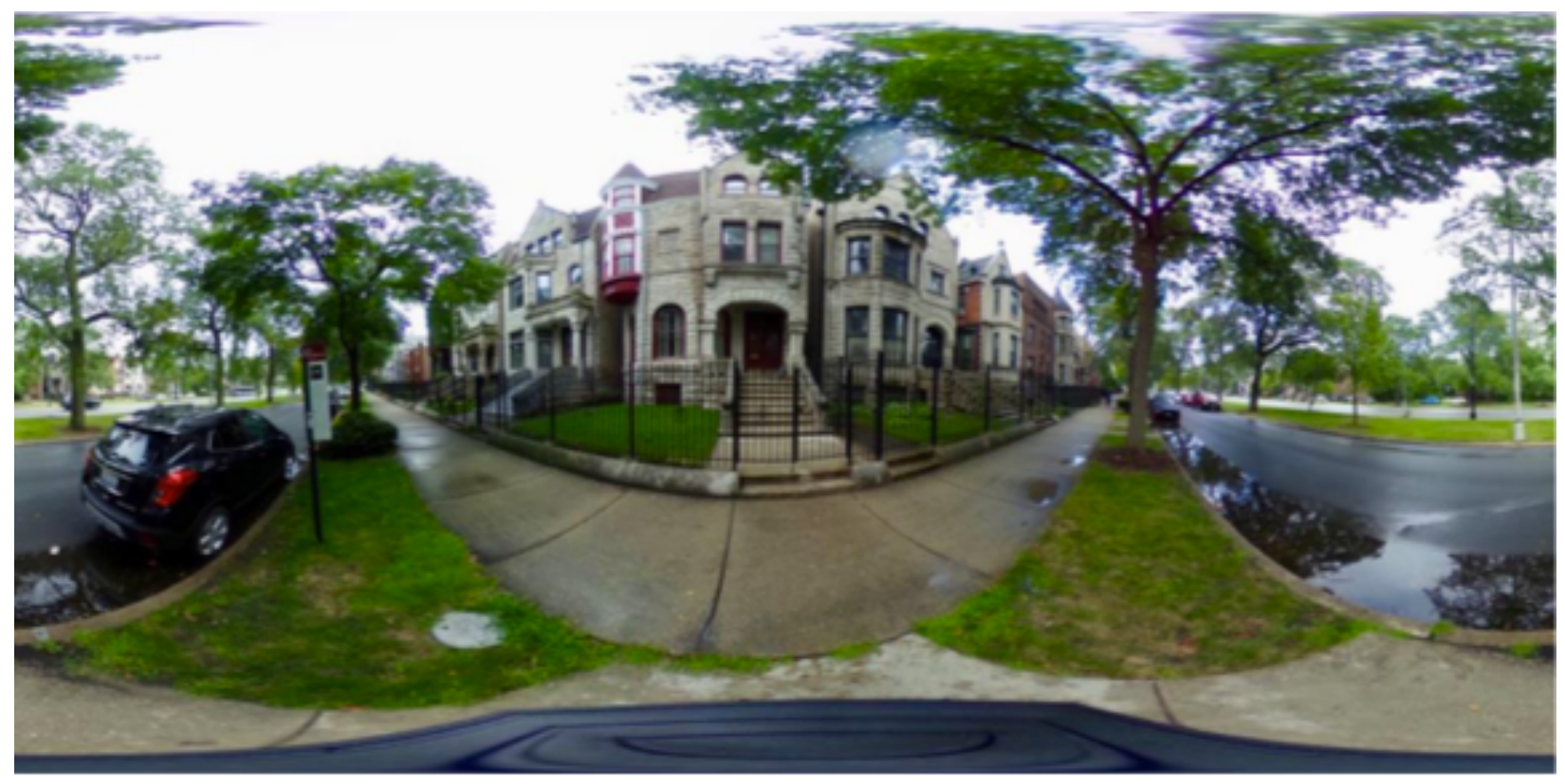

Fig. 1 Condensed reproduction of the pano image for Pano Five: Women in WWI

Pano Description: The address of Ida B. Well's Negro Fellowship League is now a parking lot under the "L" train in the Douglas neighborhood of Chicago. Throughout American history, African-American women have demonstrated patriotism, and fought for civil and women's rights. During the World War I era, their service, dedication and persistence in the face of discrimination was felt both on the battlefield and at home. 
Beginner Q: To whom did journalist Ida B. Wells write a letter of protest denouncing unfair treatment of Black officers training at Camp Funston Kansas?

Beginner A: President Woodrow Wilson

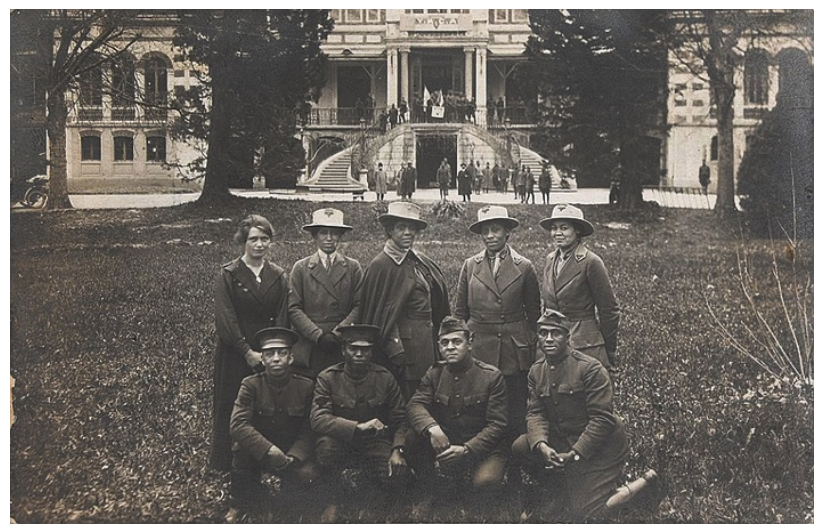

Intermediate Q: What was the National Association of Colored Women's Clubs? Intermediate A: A powerful organization formed to advance the cause of Black women's suffrage concerns. Founded in July 1896 the federation became a formidable national umbrella for local and regional women's clubs. Ida B Wells was a founder and Mary Church Terrell served as its first president.

Fig. 2 Image for POI 1 (Point of Interest)

Advanced Q: What part of our Constitution guarantees the right to vote without fear of discrimination based on gender?

Advanced A: The 19th Amendment effectively gave white women the right to vote while Blacks, both men and women, were restrained by poll taxes, violence and threats of violence and other unscrupulous assaults on American values.

POI 1 Title: African-American educator and activist Kathryn Johnson joins the efforts abroad POI 1 Description: NAACP Field Organizers Kathryn Johnson, a former Dean of Women at Shorter College, and Addie Hunton succeeded against considerable opposition in going to France in 1918 as YMCA workers to assist Black troops. A YMCA hut of similar size servicing white soldiers would provide at least six women and eight men. Yet one woman and two to five males serviced the hut holding 9,000 Black troops. Although more than 200,000 Black soldiers served overseas only six Black women were allowed to serve.

POI 2 Title: Ida B. Wells: journalist and activist for

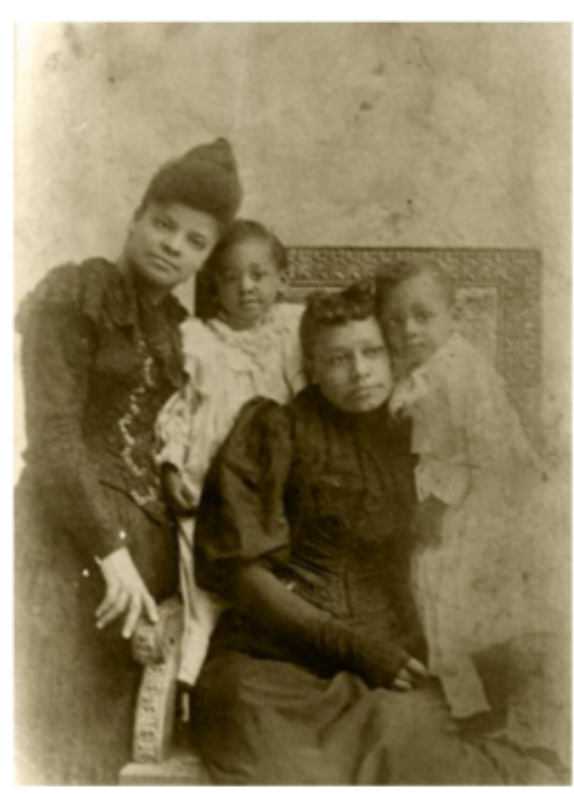
social justice.

Fig. 3 Image for POI 2 
POI 2 Description: Photo of Ida B. Wells with widow and children of Lynching victim. Ida B. Wells was one of the founding activists in the Civil Rights Movement. She advocated for those affected by the terrorist act of lynching in the South. Wells created the "Memphis Free Speech and Headlight," which was burned down by a white mob. She also co-founded the NAACP and was a suffragette, despite racism from white suffragettes.

POI 3 Title: Ida B. Wells responds to Bulletin No. 35

POI 3 Description: General C.C. Ballou issued an order to the segregated 92nd Division telling black soldiers in the unit to not patronize public places outside their training camp in Kansas where white citizens might feel uncomfortable. This prompted Wells to appeal directly to President Woodrow Wilson. Wells' letter read, in part, "No order so vicious and undemocratic has been issued in any armies fighting in Germany."

POI 4 Title: "Lifting As We Climb"

POI 4 Description: The National Association of Colored Women's Clubs immersed itself in social issues ranging from suffrage, segregation and lynching to raising money for education. Patriotism was aptly demonstrated during "The Great War" as the NACWC raised more than \$5 million to go towards war bonds. The descendant of this formidable organization, the National Council of Negro Women, remains in existence today. Pictured: "Colored American Red Cross Canteen War Workers who canteened all Colored soldier troop trains passing through Chicago to and from the front."

\section{POI 5 Title: Suffrage for almost all (video)}

POI 5 Description: White and Black women made up the Suffrage Movement. Despite the 1920 passage of the 19th Amendment, racism trumped equality, and in the South, claiming rights of liberty and womanhood could and did frequently lead to death.

Despite racial divisions, Black women were collective in their courage in the fight for equality.

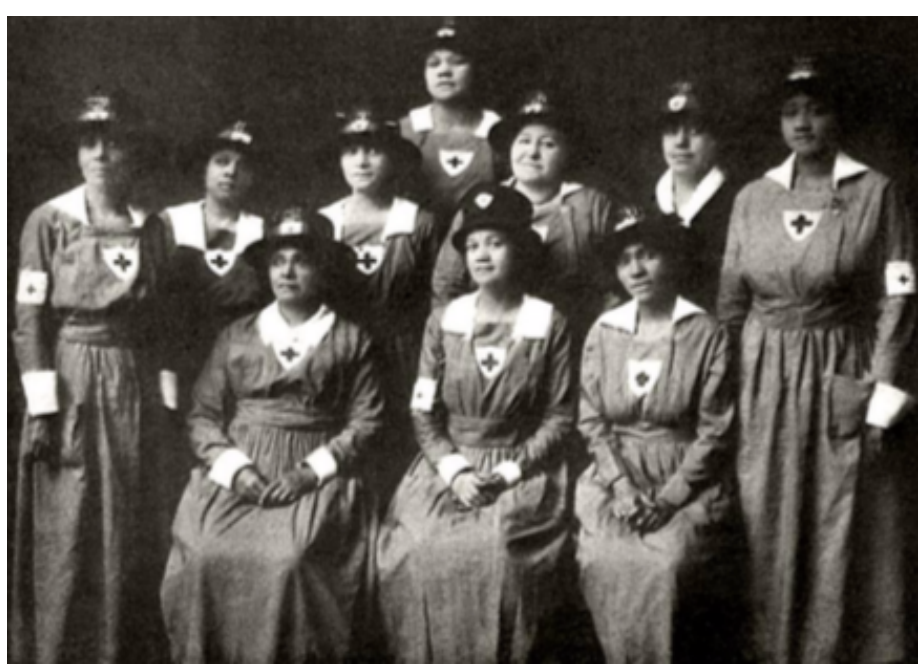

Fig. 4 POI 5

Sources: https://net.lib.byu.edu/estu/wwi/comment/scott/SCh08.htm https://catalog.archives.gov/id/7455575 http://www.blackpast.org/aah/national-association-colored-women-s-clubs-inc-1896 


\section{POI 5 Title: Suffrage For Almost All \\ Video Script:}

In 1870, 15th Amendment granted voting rights to Black men, but not women of any color. Ida B. Wells-Barnett founded the Alpha Suffrage Club in Chicago. When white organizers of the 1913 National Suffrage March in Washington, DC asked Black women to walk at the end of the parade, Wells refused, emerging from the crowd to join the white Illinois delegation.

\section{Behind the Scenes Images:}

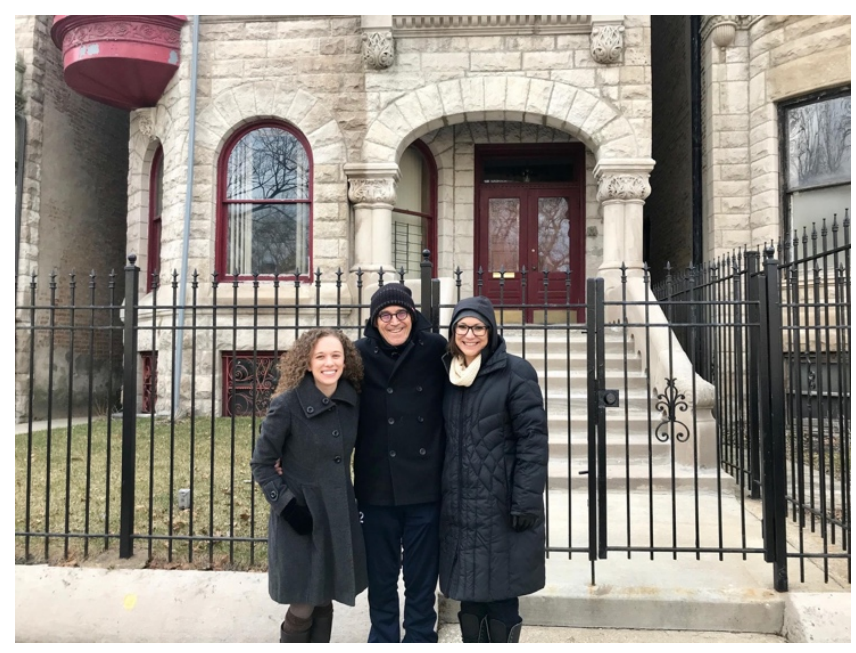

Fig. 6 Brianna Robinson, Dr. Joel Beeson and Emily Pelland (myself) in front of Ida B. WellsBarnett's house in Bronzeville, Chicago, IL on March 23, 2018.

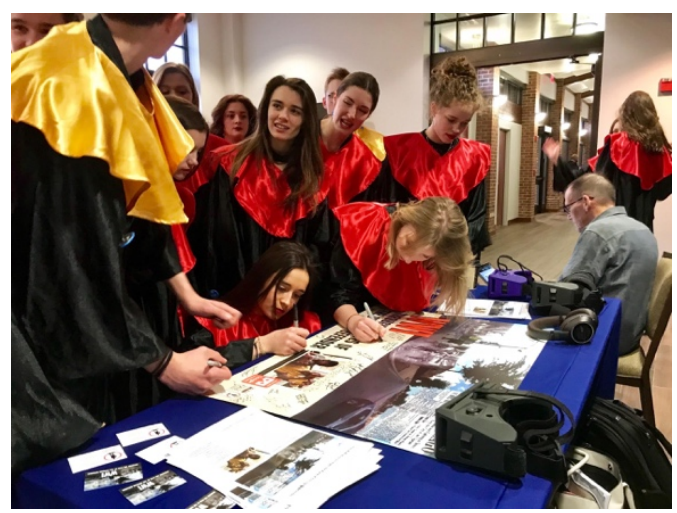


Fig. 7 French students sign the project poster before performing with the Military Academy students on March 22, 2018.

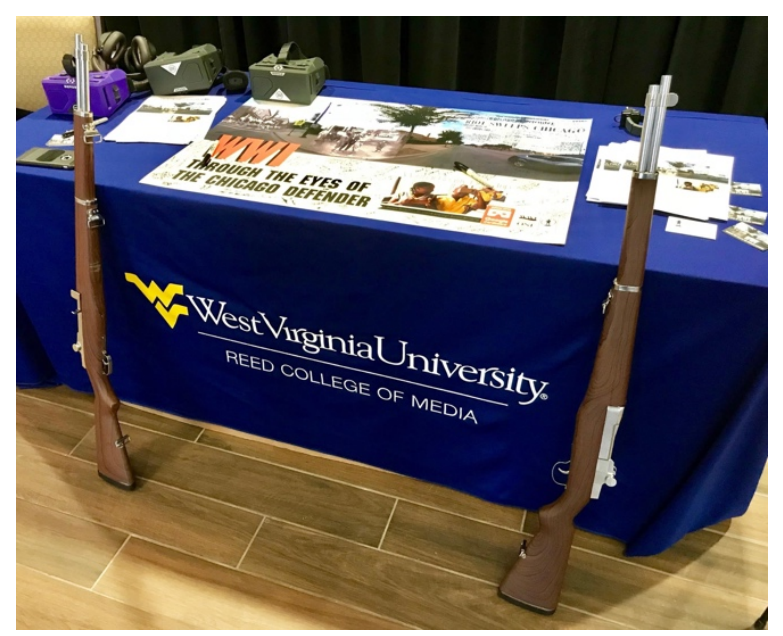

Fig. 8 The display for the Chicago Military students and the French students on March 22, 2018 in Chicago, IL.

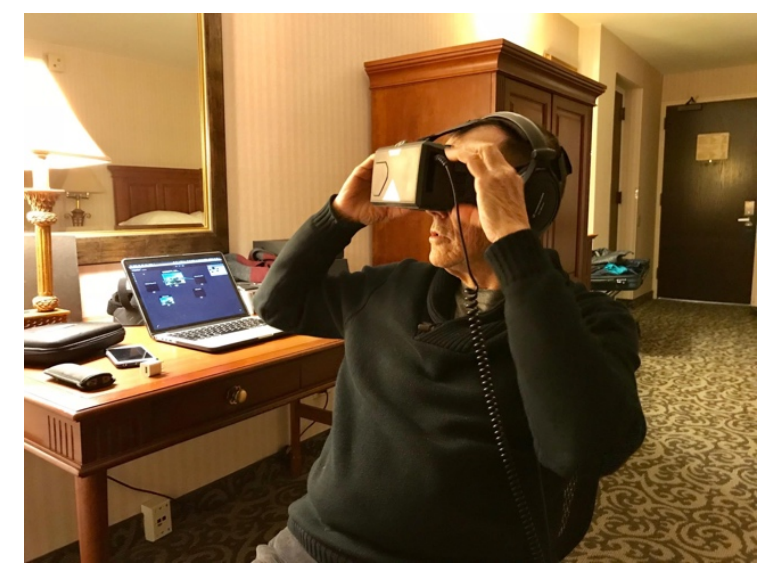

Fig. 9 Dr. Beeson tests the demo for the presentation about the Expedition for French students on March 21, 2018 in Chicago, IL. 


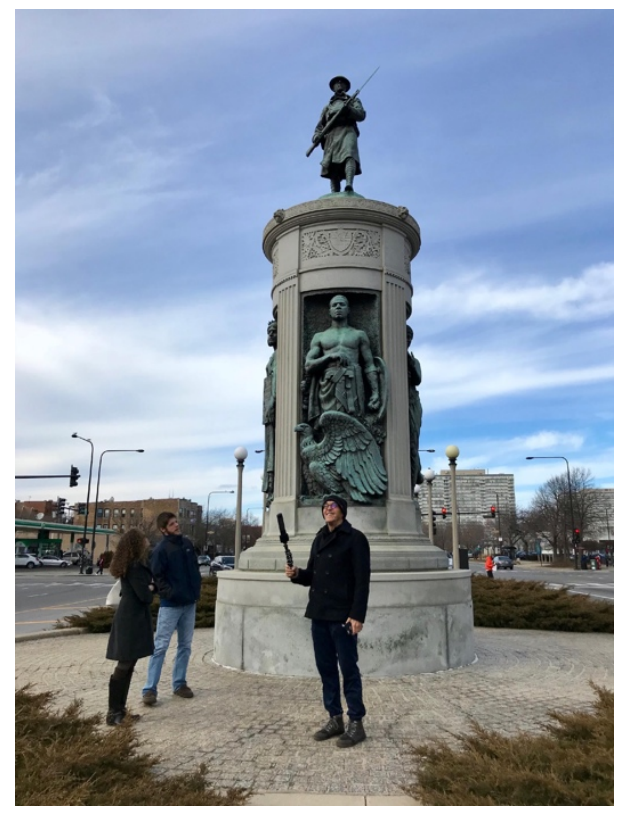

Fig.10 Victory Memorial for the $8^{\text {th }}$ Illinois in Bronzeville, Chicago, IL with a Ricoh Theta X to create the VR images for the Expedition on March 23, 2018.
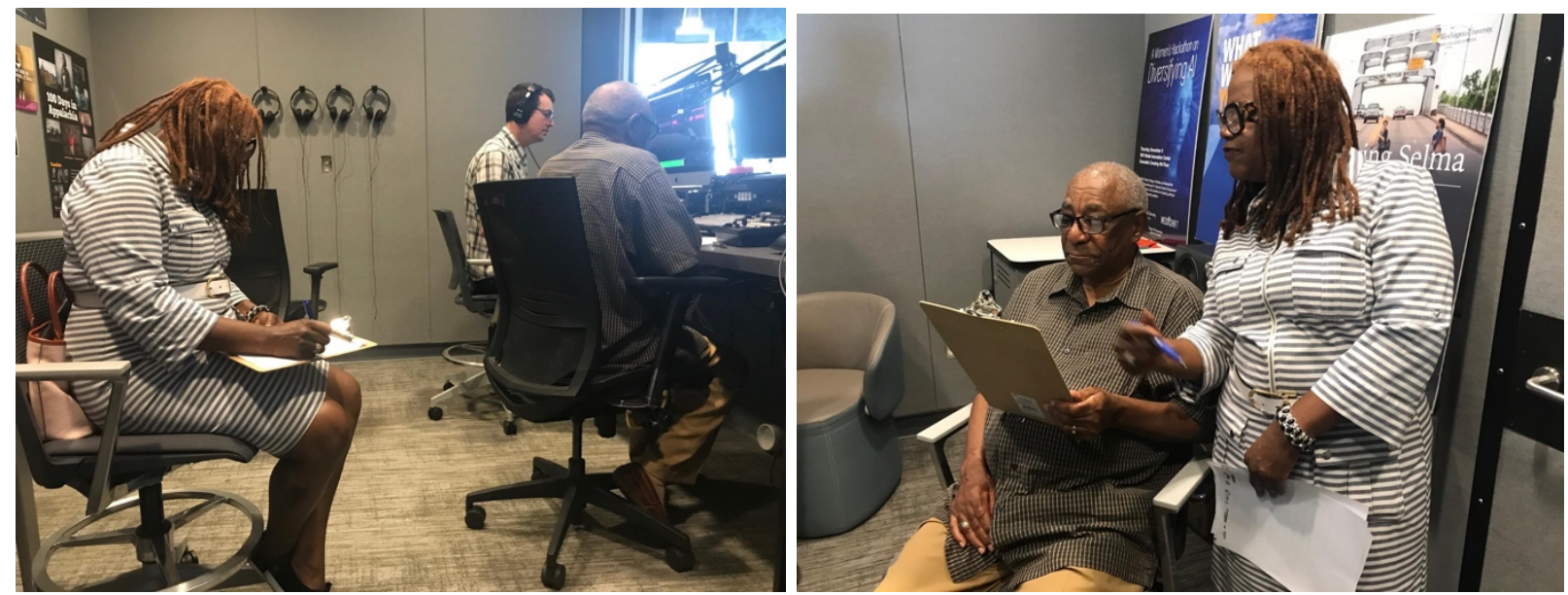

Fig. 11 Recording the Scripts in Morgantown, W.Va.

with co-producers Beverly Scott, audio engineer David Crawford and Col. Gene Scott, on June 17, 2018.

The second picture shows Col. Eugene Scott and Beverly Scott editing a script. 


\section{Professional \& Educational Qualifications}

WWI Through the Eyes of the Chicago Defender combines multiple interests of mine: history, archival research and primary documents, documentary filmmaking, and experimental journalism. Experimental journalism does not simply refer to use of innovative new technology, such as VR, but rather refers to an approach that involves questioning common practices and challenging historical assumptions, while merging old and new technologies. One aspect of challenging common practices is critiquing the assumption that journalists can be objective in their reporting, and to acknowledge that every journalist is a fallible human being who brings personal experiences, perspectives and implicit biases into reporting a story. Therefore, the most vital part of the reporting for this project involved engaging with and relying on community members to insure an authentic voice, localized experience, and place-based, culture-based history was represented. This also presented conflicts that we as white reporters needed to face, acknowledge, and learn from. To achieve this, Beverly and Colonel Scott worked as coproducers on the project.

\section{Skill Development}

The skills developed in this project included:

1) Navigating the challenges of incorporating old technologies and archival footage with new technologies and present-day footage.

2) Conducting archival research, which required searching online for digital records as well as going in person to different archives in Chicago and Washington DC to research the physical documents, some of which were 100 years old and highly delicate. 
3) Using new 360-degree capture equipment, which included a Ricoh Theta V with TA-1 3D microphone for spatial audio.

4) Partnering with community experts to diversify and strengthen reporting.

5) Working within the restrictions and formatting confines of preparing a documentary project for Google Expedition.

\section{The Research}

\section{Research Statement}

This project intends to explore how counter-narrative storytelling methods, and Critical Race and Feminist Standpoint theories can enhance reporting methodology, including techniques for community engagement, and use of new technology to disrupt conventional storytelling forms. It also attempts to contextualize history in new ways by combining archival footage with present day footage in an emerging field of technology. CRT combats deficit narratives that have plagued Americans since the birth of mass media, and FST asserts that each person comes with their own biases and experiences, all of which are valuable to reporting.

\section{Intended Audience}

The target audience is 8-12 grade students and adults with access to mobile devices and VR headsets, researchers and individuals interested in WWI history and African American history, and journalists and other documentary producers seeking new methodologies for interactive storytelling and counter-narrative storytelling.

\section{Project Methodology}

The Google Expedition utilizes 360-degree panoramic still photographs or 360-degree videos with annotated videos to explain each topic of the eight chapters in the experience. The 
panoramic images were captured with a Ricoh Theta S and a TA-1 3D microphone to capture spatial audio of the area. The archival images and videos were acquired through archives and libraries.

This project illuminates aspects of life for African Americans during World War I through the Chicago Defender. A former writer and a former publisher contributed to give the project a more authentic Chicago voice, and also captured the nuance that would otherwise be missing. The topics include the Chicago Defender, Jim Crow laws, lynching, sharecropping, convict leasing, the Great Migration, Black women in the suffragette movement, the $8^{\text {th }}$ Illinois National Guard, the $370^{\text {th }}$ Infantry, the Red Summer Riots, the post-war revival of the KKK, and the genesis of the modern civil rights movement.

A significant aspect of this project is the fact that the editors do not have direct contact with the people who experienced this firsthand. Critically, CRT and FST provide a means of framing history and acknowledging personal inequities of knowledge. This is not to say that this needs to be implemented, but rather this is an option to explore, and time will tell if this is effective or not.

Dr. Beeson writes about the project:

I think the part of the project that follows both CRT and Standpoint is attempting to see history 'through the eyes of' the Defender rather than through the eyes of the white male professor. And collaborating with Bev and Col Scott, who are the institutional memory of the daily Defender. Whether that is useful or counternarrative is an open question. We purposely are not focused on the 370th exclusively, but the WWI era for African Americans because it was such a pivotal moment that was the start of the modern civil rights movement - post-reconstruction Jim Crow Black Codes in the South, lynching, convict leasing, sharecropping; the Great Migration (largest migration in history) to the North, women's activism and suffrage, the war, economic opportunity, and the 370 th, and the aftermath and Red Summer riots. We are putting the 370 th and the War in context. It actually may be too ambitious. 
The other piece of this is to engage young people using a technology that they use daily. Whether this is good, or useful, or will engage them beyond the VR experience will depend on the community engagement part of this, which means the schools have to be involved in creating curriculum or project around the history.

\section{Project Challenges}

As Dr. Beeson stated, this project is arguably over-ambitious. Because of systemic racism and sexism, there is an over-abundance of information that has been overlooked by historians and journalists. The success of the Expedition has yet to be determined in terms of providing supplementary teaching, which is the main purpose of Google Expeditions. Nevertheless, the creative process is helpful for journalists who want to report with more nuance and local context. The team wanted to include enough content and context to allow students to have a varied and nuanced understanding of a complex historical period, and one that is still wrought with racial tensions. VR experiences fail when they attempt to include too much and become too time consuming. On top of that, Google had clear editorial limitations for all assets for Expeditions, so within those constraints, the team attempted to make each pano information-dense. One major limitation was the 30 -second video maximum. While this was a hinderance, it also became a benefit. Carefully chosen words and phrases produce tight, engrossing videos.

In addition, the team members struggled with poor leadership, the workflow, and communication. Team members worked remotely for the grand majority of this project, and remote teamwork naturally introduces communication challenges. The Scotts, who were key members of the editorial team, had to learn contemporary programs such as Slack, Google Drive, Google Docs, as well as become familiar with the emerging practices and conventions of virtual reality storytelling, which is still in an evolutionary phase as a journalistic medium. 
A very time-consuming challenge surrounded the acquisition of historical images and videos. Some photographs and motion pictures are digitized, but the majority are not. In either instance, the workflow was little to no help. Oftentimes, team members were required to analyze each individual document available in a given subject, usually without much in the way of detail of what is included in the box or folder.

The ultimate challenge of creating this Expedition was for the white creators to become more sensitive in their reporting. It forced us to deeply empathize with Black American experiences that have been overlooked and disregarded since the Europeans first invaded the Americas. Though not widely taught, Africans had visited the Americas before Europeans. Generations have felt this grave abuse, and we as white reporters must be conscientious of the detriment this causes.

Black history is not widely publicized and therefore not widely known; American history has been viewed as white/European-descended history, and other non-white Americans are the exception and ultimately ignored for their contributions. The recognition of this allows for an attuned awareness to the issues surrounding racism, sexism, and classism.

To achieve a properly reported Google Expedition about the Black American experience during WWI, the project was framed by CRT and FST. We did not realize that the experience of creating it would become a meta-case study of those theories.

During production, the white producers, myself included, experienced how to utilize CRT and FST firsthand. This experience was valuable micro-study of the application of the theories into any project, whether it is long-term or spot news.

In the process of fact-checking, a contributing writer/editor was diligently doing her job by verifying a particular fact: is the $370^{\text {th }}$ the first only-all-Black Infantry? The other writer 
focused on the facts and could not determine the validity, but the tone of the phrasing did not emphasize the magnitude of the achievements made. Beverly felt displeased with the editing. The inability to determine basic facts — such as verifying the first and only-all-Black Infantry — through diligent research emphasizes some of the issues surrounding systemic racism and sexism, including lack of accurate information. By the narrative generally provided by historians, the honor and valor of the romanticism of war belongs to white veterans, in this particular instance. The same is true with typical portrayals of the suffrage movement, with white suffragettes recognized for their contributions and Black suffragettes' contributions largely ignored or minimized, which is also a topic in the Expedition.

The conflict was emblematic of the larger issue: those who produce the facts, information, stories, etc. shape the way society is educated about the past. FST and CRT questions those methods, and during production, the team members experienced a clash of epistemology and received a much-needed lesson on the Black American experience. The project was created for the purpose of overcome the severe lack of readily available information about Black American history, and this moment allowed the white creators to realize the sensitivity of reporting on these topics and issues.

During production, Beverly felt upset by an edit that another writer made and questioned if the $370^{\text {th }}$ was in fact the "first and all-Black Infantry." It was in fact entirely African American through the level of Colonel, and the troops returned home as decorated veterans during a time of barbaric racism in the United States. Initially, I did not understand why she felt exasperated. The other writer was doing her job in ensuring accuracy, but Beverly wanted us — as white people — to listen to her perspective. 
My disregard is a symptom of exactly what we were trying to overcome: sexism and racism in reporting. Those issues cause problems in all people, including the detrimental habit of ignoring what others need and want to share. In my mind, I did not allow Beverly to share her displeasure with what turned out to be not just this situation, but the whole project. It was important to not only write accurate facts, but to also communicate the experiences of these facts. Beverly has dealt with the realities of systemic racism and sexism, arguably more than the other producers have. Beverly wanted to express her viewpoints as a co-producer and expert. Her knowledge and experience needed to be taken seriously for the project to be successful, as did her urgency to infuse more weight into the significance of information such as all-Black infantry. I needed to listen intently and then reflect, and then repeat.

While the topics were sensitive, reporting in a collaborative way is also sensitive. Reporters must rewire old journalistic methods, which can be bad habits, and be cognizant that they are not immune to misrepresentation. This new method of reporting required extensive listening and connecting with those who may not typically work on a new-tech journalism endeavor. The incident where Beverly felt insulted by an edit abruptly warned me that every word that culminates into sentences can potentially profoundly affect how an audience perceives a story. I think journalists have encouraged a working culture of arrogance that has cursed reporting. Now, we as journalists are dealing with the public's distrust of news organizations. This project alerted me to the fact that I have arrogance and therefore misconceptions that I need to check and recheck throughout production — especially during the initial research stages. And this is where listening was most important, because it directs how information is culminated and who can participate as an "expert" on the project. 
The Timeline

\section{Explanation}

The timeline relied heavily on leadership of a team of four, each of whom had separate tasks. The timeline revolved around researching archives, including the Chicago Defender archive, to find suitable images and motion pictures to accompany the panos.

\section{Work Schedule}

The workflow initially followed the panos, and each team member fulfilled their duties and alerted the team member who was next. And then onto the next pano and each task. The timeline was ongoing, and the deadline was set by Google, and then delayed until August 2018 for a release of early September 2018.

\section{Project Delivery}

This VR experience is hosted through Google Expeditions, an app-based teaching supplement for teachers. With an iPad, teachers guide their students who experience the Expedition in a headset from the app on a smartphone. The app includes other Expeditions of various topics.

\section{Literature Review: Critical Race Theory and Feminist Standpoint Theory to Cultivate Non-Fiction Stories}

There are examples of projects previously published that utilize CRT and FST, and this report provides three different projects framed through those theories. These theories, as well as the Expedition, provide ideas of how a reporter or news organization may implement CRT and FST into the storytelling process. Using these theories will ultimately allow reporters to acknowledge that each person has their own biases, standpoints, and valid stories. 
The first example, and the most fitting for this context, is the dissertation by the director of the Expedition, Dr. Joel Beeson. Dr. Beeson wrote his doctoral dissertation surrounding CRT and FST in practice called Until Lions Have Their Own Historians: On Critical Race Theory, Oral History and Counter-Storytelling in a Documentary Project (2012). This dissertation combines Critical Race Theory and Feminist Standpoint Theory with Oral History to experiment with unconventional reporting for his documentary about WWII veterans. The dissertation acknowledges the contradictions of implementing theory into practice and presents ways for reporters to reevaluate information gathering and presentation methods.

One of the most significant aspects of his documentary is the collaboration with veterans and their families. Their family photographs and recorded oral recounts provided a deep wealth of knowledge for a project that specific targeted overlooked stories in American history. The theory assumes that each person's perception of the world is affected by their societal standing. Therefore, the data may not only derive from academics or others typically sought out as experts, but from "ordinary" people. Those contributors can become collaborators on a project, and the interaction between the collaborators (reporter and expert) creates another set of data to understand. Standpoint Theory in the practice of journalism rejects the idea that reporters are inherently neutral and objective, and states that journalists need to acknowledge their own biases in order to create more nuanced, honest stories.

In similar fashion, the Expedition relied on acquiring data from those closest to the story. A former publisher of the Chicago Defender, Col. Gene Scott, and a former reporter for the Chicago Defender, Beverly Scott, acted as producers to provide a genuine narrative to the project which uses reports from the Chicago Defender as its lens. While they may not have lived in the era of WWI, their experiences provided empirical, valuable evidence for the Expedition. 
The Expedition utilized FST in its efforts to not only acknowledge those who fought in World War I — the $8^{\text {th }}$ Illinois and $370^{\text {th }}$ Infantry — but also those who also fought battles in this country during and after the war. Black women played a tremendous role in activism for gender, racial, and economic equality, and eventually the civil rights movement. Meenakshi Gigi Durham argues in On the Relevance of Standpoint Epistemology to the Practice of Journalism: The Case for "Strong Objectivity" that the journalistic practice of striving for complete objectivity and freedom from bias in reporting actually helps to perpetuate derisive stereotypes. Durham writes that the ideology of objectivity in newsgathering did not arise until 1931 as a possible backlash to WWI propaganda. This is quite significant as the Expedition begins in the era of WWI. Journalism, in the post Great War era, was associated with neutrality that separated fact from opinion. The Expedition keeps in mind of deficit narratives while creating a counternarrative in response. The oral history uses the technology of a singular speaker, while the Expedition utilizes the mass media technology of VR to help disrupt conventional narrative conventions, and in turn, aids in the education of the user.

Even with (Feminist) Standpoint Theory, there can be the tendency to overlook race. The Expedition discusses how white women tried to exclude Black women from the suffragette movement, and how Ida B. Wells persevered despite threats. Durham quotes bell hooks (1984):

Often white women who are busy publishing papers and books on "unlearning racism" remain patronizing and condescending when they relate to black women. This is not surprising given that frequently their discourse is aimed solely in the direction of a white audience and the focus solely on changing attitudes rather than addressing racism in a historical and political context. They make us the "objects" of their privileged discourse on race. As "objects," we remain unequals, inferiors. Even though they may be sincerely concerned about racism, their methodology suggests they are not yet free of the type of paternalism endemic to white supremacist ideology. 
This statement reflects ideology during the Expedition's era and the present day. Oftentimes, the fight for equality in reflection perpetuates the racist and sexist structures and perceptions in society. The study of both FST and CRT provide tools for reporters creating projects on overlooked, commonly traumatic, historical or present-day stories. The premise of this project is that the use of history provides invaluable data, context and insights to the conditions of a present-day story.

An example of how to implement CRT in a non-fiction project can be found in Critical Race Media Projects: Counterstories and Praxis (Re)Claim Chicana/o Experiences by Sonya M. Alemán and Enrique Alemán, Jr. They describe a Critical Race media project as a multimedia project with a "counter storytelling focus" by combining activism and research to provide honest, nuanced narratives about people of color through the frame of CRT. The two projects described in this article include a university student newspaper and a documentary. This article utilizes solid examples of how to implement CRT into storytelling endeavors, which complement the spirit and mission of the Expedition.

The first Critical Race project describes the University of Utah student newspaper Vencermos. Sonya Alemán writes, “As a Chicana from South Texas with a vested interest in the mediated representations of my community, I was drawn to Venceremos" challenge of mainstream imagery and messages about Latinas/os through a trove of untold stories via an idiosyncratic journalism practice." She rooted the newspaper in a course designed around CRT. Alemán writes, "the pedagogical approach for the class has resulted in publications that reimagine a journalism education that instills reporting skills better suited to representing communities of color." She argues that the change in reporting also changed how students consume media and express forms of activism, and therefore impacts the community-at-large. 
The Expedition aims to impact students and teachers with the lessons from hidden parts of American history, because Black history is American history.

The second Critical Race project in the Alemán article is Stolen Education, a documentary written and produced by the authors. Stolen Education documents Sonya Alemán's endeavor to "re-claim" the story of Hernandez et al. v. Driscoll Consolidated Independent School District (1957). Most reporters would emphasize the role of the attorneys, but she told the story from the point of view from the schoolchildren who experienced discrimination. "I document their educational experiences and chronicle what happened when the students who testified in the case went back to school the next day. I wanted to describe the courage of young people, testifying in an era when fear and intimidation were tools used in maintaining racial hierarchy where legal, economic, and educational institutions were controlled and managed solely by Whites.” Additionally, she interviewed Chicana/o scholars with South Texas roots (where the case took place) in the fields of history, women's ethnics studies, and bilingual education. She also interviewed white residents and members of the educational board there all of whom are white.

Despite challenges, our Google Expedition project succeeded in producing a thorough, nuanced documentary about a critical aspect of American history. Likewise, the impactful additions from the Scotts not only provided a wider range of expertise, it broadened the scope of those connected to the project and led to a network of people interested in (and would benefit from) the Expedition. It also led to this next point about producers having more than a professional stake in the project.

Critical Race methodologies elicit and center the "voices" and experiences of marginalized communities and students. Alemán writes, “Critical race theoretical tenets also 
steered the storytelling to uncover the dominant discourses that repress stories of racial tension and resilience through denials and mis-remembrances. Disrupting normalized ideologies that maintain a White supremacist status quo is a consistent thread of critical race scholarship, and similarly informs critical race media projects."

According to the authors, Critical Race documentaries use a crew personally invested in the story. These documentaries should also aim to contribute to academic research through the addition to the historic narrative of an underrepresented story conveyed with compassion. Unlike conventional journalism which assumes objectivity, the author argues that the documentary — or any Critical Race project — must acknowledge the background of the researcher, and for Alemán, she felt a connection through her deceased mother, who she discovers testified in the landmark case that was arguable the first successful Brown litigation. She writes in the article, "the memories in the documentary offer layered and nuanced understanding of race relations, a racialized silence, and continued segregation in small-town Texas."

Similarly, the Expedition could be considered a Critical Race documentary because of the ways it utilizes CRT, much like Venceremos and Stolen Education. The producers of the project invested professionally as well as personally. A former publisher and former reporter for the Chicago Defender contributed to the narrative voice by providing context and nuance to the stories covered in the monumental paper. A diverse team of talents and expertise allowed for the Expedition to be thoughtful about race, gender, and class. The goal was to connect the viewer to the topic as much as the researchers were connected. Because of the traumatic topics, reporters require a deeper level of compassion and empathy towards the subjects and subject matter.

The Expedition was an experiment, but it challenged the creators to think expansively in both technology and storytelling in the realm of critically analyzing the systematic patterns of 
race throughout history from the early 1900 s to the present-day. As Alemán writes, "critical race theory's unequivocal conviction that race and racism are both enduring and endemic aspects of U.S. society is useful, as is critical race theory's critique of objectivity." In addition, practicing CRT also allowed reporters (and student reporters) to see certain predictable tropes and stereotypes that are engrained in mainstream news reports. The Expedition seeks to combat deficit narrative surrounding Black and African American history.

While the project faced challenges and limitations as outlined in this report, it was nonetheless successful in that it achieved the following: 1) successful utilization of emerging VR technology to bring to life under reported aspects of American history; 2) The successful production and publication of the Google expedition meeting all of Google's precise formatting requirements; 3) The development of a template for teammates to use new workflow programs and process to yield greater productivity in complex collaboratively authored projects;

4) The establishment of an understanding about the sensitivity of each participant in the project. When there is a cross-cultural team, an attentiveness to how each person is affected by the topics can yield stronger working relationships and ultimately enhances the project overall.

Ultimately, the primary key to the success of this project was the inclusion of Beverly Scott and Col. Gene Scott as key authors and editors on the team. Their experiences with the Chicago Defender provided nuance and context that the research members of the team would not have been able to access or realize as individuals without any direct connection to the Chicago Defender, the place-based history of the Chicago locations and experiences, let alone of the African American or Black American experience. For the Expedition, we aimed to create a nuanced narrative about ancestors, and that requires the writer, or the knowledge-creator, to listen intently from varying experts in the community. 


\section{Bibliography}

Batsell, J. (2015). Engaged Journalism: Connecting with Digitally Empowered News Audiences.

New York: Columbia University Press.

Becker, H. S. (2012). Art Worlds. Berkeley, Calif: University of California Press.

Becker, H. S. (1986). Doing Things Together: Selected Papers. Evanston, IL: Northwestern University Press.

Berger, J. (2008). Ways of Seeing. London: Penguin.

Beeson, J. (2012). Until Lions Have Their Own Historians: On Critical Race Theory, Oral History and Counter-Storytelling in a Documentary Project (Doctoral dissertation). Retrieved from ProQuest Dissertations and Theses. (Order No. Order No. 3532512)

Bolton, R. (1999). The contest of meaning: critical histories of photography. Cambridge, MA: MIT Press.

Collins, P. H. (2015). Black Feminist Thought: Knowledge, Consciousness, and the Politics of Empowerment. New York: Routledge.

Delgado, R., Stefancic, J., \& Harris, A. P. (2017). Critical Race Theory: An Introduction. New York: New York University Press.

doi:https://uniteyouthdublin.files.wordpress.com/2015/01/richard_delgado_jean_stefancic_critic al_race_thbookfi-org-1.pdf

Harding, S. G. (2009). The Feminist Standpoint Theory Reader: Intellectual and Political Controversies. London: Routledge.

Huxford, J. (2001). Beyond the referential. Journalism: Theory, Practice \& Criticism, 2(1), 4571. doi:10.1177/146488490100200102 
Massey, D. S. (2009). Racial Formation in Theory and Practice: The Case of Mexicans in the United States. Race and Social Problems, 1(1), 12-26. http://doi.org/10.1007/s12552-009-90053

Solutions Journalism Network https://www.solutionsjournalism.org 